\title{
Research Article \\ Effect of Water-Cement Ratio on Pore Structure and Strength of Foam Concrete
}

\author{
Zhongwei Liu, ${ }^{1,2}$ Kang Zhao, ${ }^{1} \mathrm{Chi} \mathrm{Hu}^{2}$ and Yufei Tang ${ }^{1}$ \\ ${ }^{1}$ Department of Materials Science and Engineering, Xian University of Technology, Xi'an 710048, China \\ ${ }^{2}$ Sichuan College of Architectural Technology, Deyang 618000, China \\ Correspondence should be addressed to Kang Zhao; kzhao@xaut.edu.cn
}

Received 4 August 2016; Revised 18 September 2016; Accepted 22 September 2016

Academic Editor: Sumin Kim

Copyright (C) 2016 Zhongwei Liu et al. This is an open access article distributed under the Creative Commons Attribution License, which permits unrestricted use, distribution, and reproduction in any medium, provided the original work is properly cited.

\begin{abstract}
Foam concrete with different dry densities $\left(400,500,600,700\right.$, and $\left.800 \mathrm{~kg} / \mathrm{m}^{3}\right)$ was prepared from ordinary Portland cement (P.O.42.5R) and vegetable protein foaming agent by adjusting the water-cement ratio through the physical foaming method. The performance of the cement paste adopted, as well as the structure and distribution of air pores, was characterized by a rheometer, scanning electron microscope, vacuum water saturation instrument, and image analysis software. Effects of the water-cement ratio on the relative viscosity of the cement paste, as well as pore structure and strength of the hardened foam concrete, were discussed. Results showed that water-cement ratio can influence the size, distribution, and connectivity of pores in foam concrete. The compressive strength of the foam concrete showed an inverted V-shaped variation law with the increase in water-cement ratio.
\end{abstract}

\section{Introduction}

Foam concrete has been widely used in roofing materials, wall materials, sound absorbing materials, underground backfill, and other applications because of the material's characteristic light weight, good thermal insulation, excellent seismic behavior, and low noise and pollution [1]. At present, related studies mainly focus on the effect of admixture on the performance of foam concrete [2-5], as well as the correlation of pore structure and absolute dry density of foam concrete with the material's strength, thermal conductivity, and sound absorption. w/c ratio is an important factor that influences foam concrete performance [6-11]. Existing research on the effect of w/c ratio on the pore structure and performance of foam concrete mainly emphasizes high-porosity foam concrete (porosity > 85\%) [12-14]. By contrast, few studies have discussed the influences of $\mathrm{w} / \mathrm{c}$ ratio on the pore structure and performance of ordinary foam concrete (porosity $<85 \%)$ [15]. Jiang et al. [13] investigated the effect of w/c ratio on the pore structure of high-porosity foam concrete. The scholars found that when $\mathrm{w} / \mathrm{c}<0.8$, the pores were small, irregularly shaped, and highly connected. When w/c > 0.8 , the pores were round and expansive, accompanied with a widened pore diameter distribution range. Krämer et al. $[16,17]$ explored the formation of pore shells in foam concrete and the pore shell enhancement mechanism of volcanic ash. She found that adding volcanic ash when preparing foam concrete can enhance foam concrete strength. Ley et al. [18] studied the physical and chemical properties of pore shells in cement paste and found that air entraining agents could influence the pore shells to a certain extent. Chen et al. [3] prepared foam concrete using circulating fluidized bed fly ash. The group found that bubbles in cement paste of high consistency are easily broken during stirring and the density of the corresponding concrete increases during such process. Paste consistency could be adjusted by adding a water reducer. Meanwhile, Hilal et al. $[19,20]$ analyzed the coupling relationship between bubbles under natural and stress states during foam concrete coagulation and pores in hardened foam concrete. The scholars found that the bubbles combined during the stirring and coagulation of foam concrete, thereby expanding the pore diameter distribution of the foam concrete and reducing the foam concrete's strength. Yang and Lee [21] studied the influences of water-binder ratio and fly ash content on foam concrete performance. The scholars reported that, with the increase in water-binder ratio, the amount of 
TABLE 1: The physical properties of cement.

\begin{tabular}{lccccc}
\hline Material & $\begin{array}{c}\text { Blaine fineness } \\
\left(\mathrm{m}^{2} / \mathrm{kg}\right)\end{array}$ & $\begin{array}{c}\text { Initial setting } \\
\text { time } \\
(\mathrm{min})\end{array}$ & $\begin{array}{c}\text { Final setting } \\
\text { time } \\
(\mathrm{min})\end{array}$ & Soundness & $\begin{array}{c}3 \mathrm{~d} \text { compressive } \\
\text { strength }(\mathrm{MPa})\end{array}$ \\
\hline P.O42.5R & 343 & 91 & 210 & qualified & 28.7 \\
strength $(\mathrm{MPa})$
\end{tabular}

TABLE 2: The main chemical composition of cement (wt\%).

\begin{tabular}{lccccccccc}
\hline Compositions (\%) & $\mathrm{SiO}_{2}$ & $\mathrm{Al}_{2} \mathrm{O}_{3}$ & $\mathrm{Fe}_{2} \mathrm{O}_{3}$ & $\mathrm{CaO}$ & $\mathrm{MgO}$ & $\mathrm{SO}_{3}$ & $\mathrm{Na}_{2} \mathrm{O}$ & $\mathrm{K}_{2} \mathrm{O}$ & Loss of ignition \\
\hline Content & 21.6 & 4.9 & 2.50 & 63.4 & 1.80 & 2.14 & 0.14 & 0.37 & 3.15 \\
\hline
\end{tabular}

microcapillaries decreased, whereas those of macrocapillaries and artificial pores increased. Such occurrence resulted in the higher porosity and lower strength of the resultant foam concrete. Wei et al. [22] investigated the coagulation and hardening behaviors of foam concrete and discovered that shortening the coagulation time by accelerating hydration can effectively enhance foam concrete stability.

Although these works have analyzed many factors influencing the pore structure of ordinary foam concrete and the effect of $\mathrm{w} / \mathrm{c}$ ratio on high-porosity foam concrete, none explored the effect of $\mathrm{w} / \mathrm{c}$ ratio on the pore structure of ordinary foam concrete. In this paper, we discussed the effects of $\mathrm{w} / \mathrm{c}$ ratio on cement paste liquidity and pore structure and foam concrete strength. Results could provide reference for the preparation of lightweight, high-strength foam concrete.

\section{Experimental}

2.1. Materials. The cement used was P.O.42.5R cement produced by the Sichuan Deyang Lisen Cement Co., Ltd. The physical properties and chemical composition of the cement are shown in Tables 1 and 2, respectively. Meanwhile, the foaming agent employed was vegetable protein foaming agent manufactured by Sichuan Xinhan Corrosion Protection Engineering Co., Ltd.

2.2. Preparation. According to Table 3, cement and water were poured into a $15 \mathrm{dm}^{3}$ horizontal type mixer (GH15, Beijing Guanggui Jingyan Foamed Concrete Science \& Technology Co., Ltd.) and mixed at a rate of $40 \mathrm{rpm}$ for $120 \mathrm{~s}$ at $25^{\circ} \mathrm{C}$ to generate paste. Meanwhile, the foaming agent was diluted with water at the proportion $1: 15$. Next, protein foam produced by a foam generator (ZK-FP-20, Beijing Zhongke Zhucheng Building Materials Co., Ltd.) was injected into a foam concrete mixer and stirred for $120 \mathrm{~s}$. Next, the foam concrete was poured into a mold and maintained in static for $24 \mathrm{~h}$. After demolding, the foam concrete was subjected to standard maintenance $\left(20 \pm 2^{\circ} \mathrm{C}\right.$; $\left.\mathrm{RH}>95 \%\right)$ for 28 days.

2.3. Test Method. Relative viscosity was tested using a rotary viscometer (NXS-11A, Chengdu Instrument Factory, China). The microstructures of the specimens were determined by scanning electron microscopy (SEM; Hitachi JSM-7500F). Next, black-white binarization processing of images was conducted. Finally, pore structure parameters (e.g., pore diameter and distribution) were acquired directly using the Image-Pro Plus 6.0 image analysis software (launched "Count/siz" under the Measure menu in Windows).

Volume density and compressive strength tests of the foam concrete complied with the Chinese Foamed Concrete standard (JG/T 266-2011). The compressive strength of the specimens was measured by a fully automatic, constant stress testing machine (JYE-300A, Beijing Jiwei Testing Instrument Co., Ltd., China) under a loading rate of $200 \mathrm{~N} / \mathrm{s}$. The true density $\left(\rho_{1}\right)$ of the specimens was tested in accordance with the Cement Density Measurement Method standard (GB/T 208-2014), The absolute dry volume density of the specimens was denoted by $\rho_{2}$. Then, the porosity of specimens was determined using the following formula:

$$
P=\frac{\rho_{1}-\rho_{2}}{\rho_{1}} \times 100 \%
$$

where $P$ is the porosity of the specimens (\%), $\rho_{1}$ is the true density of the specimens $\left(\mathrm{kg} / \mathrm{m}^{3}\right)$, and $\rho_{2}$ is the volume density of the specimens $\left(\mathrm{kg} / \mathrm{m}^{3}\right)$.

The open porosity of the foam concrete was assessed. The testing principle involved the pressing of water into the open pores inside the foam concrete by exploiting negative pressure. The open pores were filled with water, and the absorbed water volume corresponds to the volume of the open pores. An intelligent concrete vacuum water saturation instrument (SW-6, Beijing Shengshi Weiye Science \& Technology Co., Ltd.) was used in the test. After the specimens were placed, the air cock of the vacuum chamber was switched on until the vacuum reached lower than $-0.08 \mathrm{MPa}$. This negative pressure was then maintained for $3 \mathrm{~h}$, after which water was injected. Next, we applied vacuum for another $2 \mathrm{~h}$ and then allowed the vacuum chamber to recover to normal pressure. The foam concrete was removed and weighed $22 \mathrm{~h}$ later. Open porosity $\left(P_{O}\right)$ and closed porosity $\left(P_{C}\right)$ were calculated using (1), (2), and (3).

$P_{O}$ of the specimens was calculated as

$$
P_{O}=\frac{m_{2}-m_{1}}{V} \times \frac{1}{\rho_{W}} \times 100 \%
$$

where $m_{1}$ is the dry material mass $(\mathrm{kg}), m_{2}$ is the material mass under the water-saturated state $(\mathrm{kg}), \rho_{W}$ is the water density $\left(\mathrm{kg} / \mathrm{m}^{3}\right)$, and $V$ is the natural volume of the material. 
TABLE 3: Mix proportions of raw materials.

\begin{tabular}{|c|c|c|c|c|c|}
\hline Mixes designation & Design density $\left(\mathrm{kg} / \mathrm{m}^{3}\right)$ & Cement (g) & Water (g) & $\mathrm{w} / \mathrm{c}$ & Foam $(\mathrm{mL})$ \\
\hline $400-0.40$ & 400 & 2909 & 1164 & 0.40 & 5883 \\
\hline $400-0.45$ & 400 & 2909 & 1309 & 0.45 & 5737 \\
\hline $400-0.50$ & 400 & 2909 & 1455 & 0.50 & 5592 \\
\hline $400-0.55$ & 400 & 2909 & 1600 & 0.55 & 5446 \\
\hline $400-0.60$ & 400 & 2909 & 1745 & 0.60 & 5301 \\
\hline $500-0.40$ & 500 & 3636 & 1454 & 0.40 & 5353 \\
\hline $500-0.45$ & 500 & 3636 & 1636 & 0.45 & 5171 \\
\hline $500-0.50$ & 500 & 3636 & 1818 & 0.50 & 4990 \\
\hline $500-0.55$ & 500 & 3636 & 2000 & 0.55 & 4808 \\
\hline $500-0.60$ & 500 & 3636 & 2182 & 0.60 & 4626 \\
\hline $600-0.40$ & 600 & 4364 & 1746 & 0.40 & 4824 \\
\hline $600-0.45$ & 600 & 4364 & 1964 & 0.45 & 4606 \\
\hline $600-0.50$ & 600 & 4364 & 2182 & 0.50 & 4387 \\
\hline $600-0.55$ & 600 & 4364 & 2400 & 0.55 & 4169 \\
\hline $600-0.60$ & 600 & 4.364 & 2618 & 0.60 & 3951 \\
\hline $700-0.40$ & 700 & 5091 & 2036 & 0.40 & 4294 \\
\hline $700-0.45$ & 700 & 5091 & 2291 & 0.45 & 4040 \\
\hline $700-0.50$ & 700 & 5091 & 2546 & 0.50 & 3785 \\
\hline $700-0.55$ & 700 & 5091 & 2800 & 0.55 & 3531 \\
\hline $700-0.60$ & 700 & 5091 & 3055 & 0.60 & 3276 \\
\hline $800-0.40$ & 800 & 5818 & 2327 & 0.40 & 3765 \\
\hline $800-0.45$ & 800 & 5818 & 2618 & 0.45 & 3474 \\
\hline $800-0.50$ & 800 & 5818 & 2909 & 0.50 & 3183 \\
\hline $800-0.55$ & 800 & 5818 & 3200 & 0.55 & 2892 \\
\hline $800-0.60$ & 800 & 5818 & 3491 & 0.60 & 2601 \\
\hline
\end{tabular}
follows:

Meanwhile, $P_{C}$ of the specimens were determined as

$$
P_{C}=P-P_{O}
$$

\section{Results and Discussion}

3.1. Effect of $w / c$ Ratio on the Rheological Properties of Cement Paste. Foam concrete density is mainly adjusted through foam dosage; hence, cement pastes with same w/c ratios exhibit consistent rheological properties. In this experiment, the rheological properties of the cement pastes of different $\mathrm{w} / \mathrm{c}$ ratios $(0.40,0.45,0.50,0.55$, and 0.60$)$ were evaluated and used to interpret the effect of the bubble maintenance of the cement pastes on the pore structure of hardened foam concrete. Cement paste is a kind of non-Newtonian fluid, and its relative viscosity equals the shear stress/shear rate:

$$
\eta=\frac{\tau}{D_{S}}
$$

where $\eta$ is the relative viscosity, $\tau$ is the shear stress, and $D_{S}$ is the shear rate.

The effect of $\mathrm{w} / \mathrm{c}$ ratio on the rheological properties of cement paste is shown in Figure 1. We calculated from (4) that the relative viscosities of cement pastes with $0.40,0.45$, $0.50,0.55$, and $0.60 \mathrm{w} / \mathrm{c}$ ratios were $0.4075,0.2737,0.0594$, 0.0255 , and $0.0159 \mathrm{~Pa} \cdot \mathrm{s}$, indicating that the relative viscosity

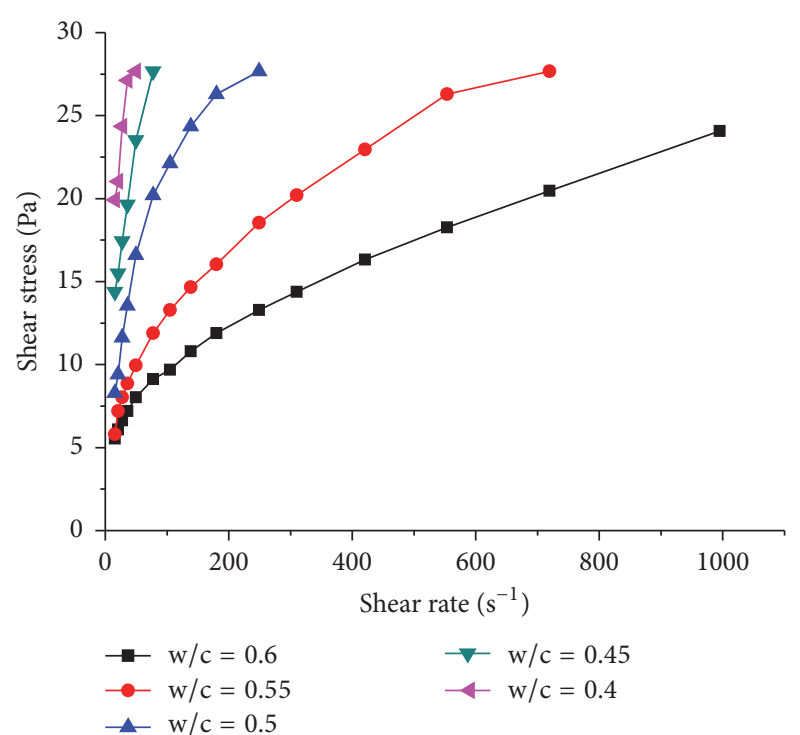

FIGURE 1: Effect of w/c on the rheological properties of cement paste.

of cement paste decreases gradually with the increase of w/c ratio. This result is achieved because the water film on the cement particle surface thickens with the increase in $\mathrm{w} / \mathrm{c}$ ratio, thus reducing the relative viscosity of cement paste [23]. 


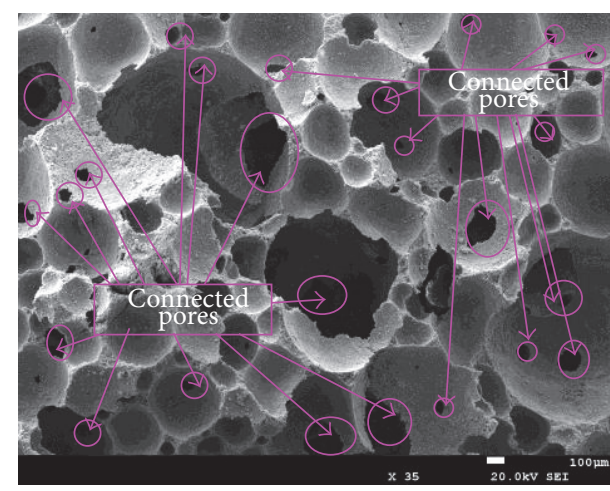

(a) $500-0.40 \times 35$

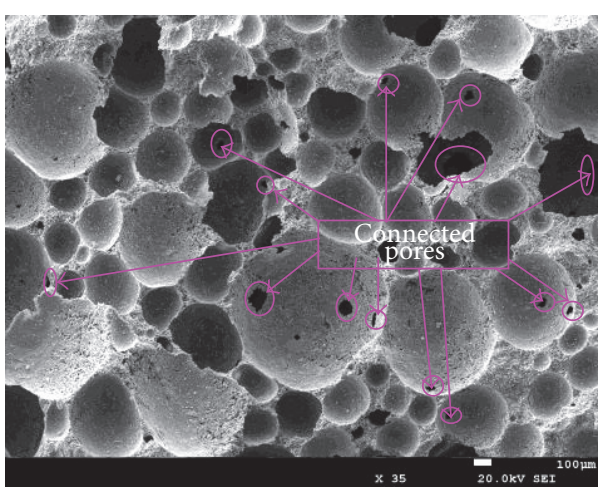

(c) $500-0.50 \times 35$

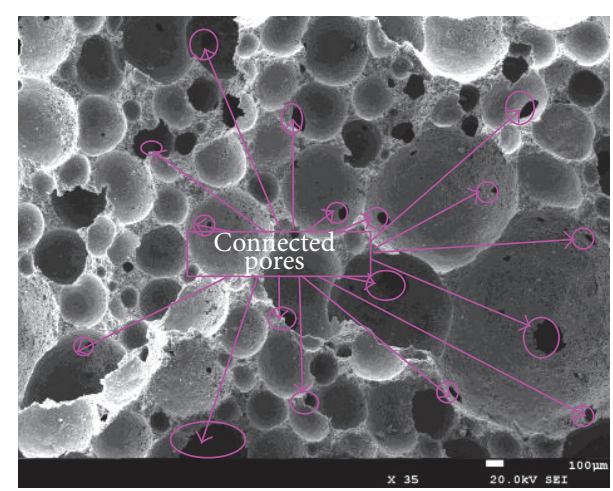

(b) $500-0.45 \times 35$

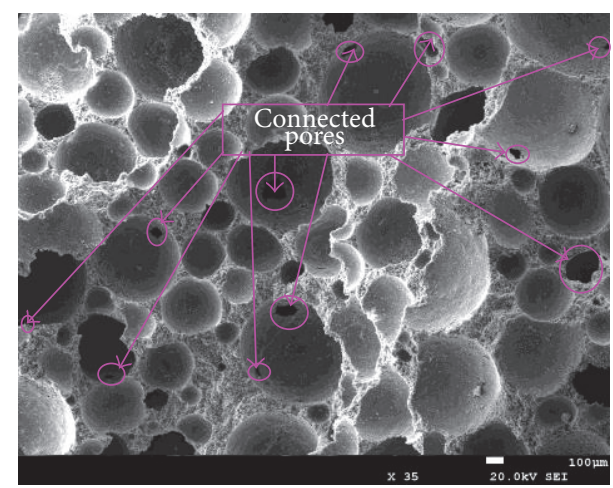

(d) $500-0.55 \times 35$

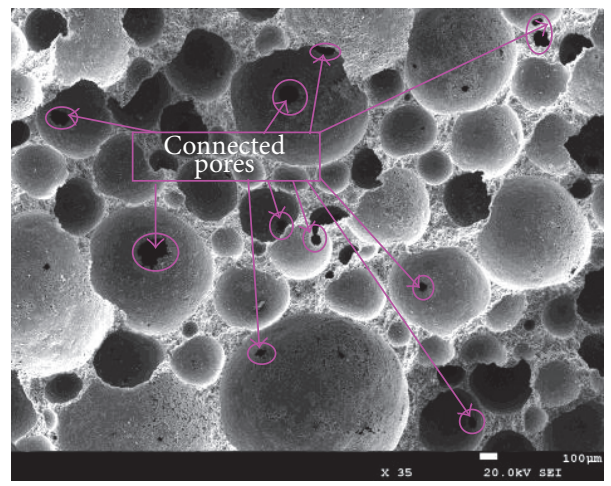

(e) $500-0.60 \times 35$

FIGURE 2: SEM images of the $500 \mathrm{~kg} / \mathrm{m}^{3}$ foam concrete of different w/c ratios.

\subsection{Effect of $w / c$ Ratio on the Foam Concrete Pore Structure.} Figures 2 and 3 show the SEM images of 500 and $800 \mathrm{~kg} / \mathrm{m}^{3}$ foam concrete samples of different w/c ratios. (1) The foam concrete with smaller w/c ratio exhibited a greater number of connected pores. This result may be due to the notion that the smaller w/c ratio would bring a higher proportion of small pores in foam concrete and a larger surface area, finally resulting in thinner pore walls and more connected pores [24]. (2) The foam concrete with smaller dry density displayed more connected pores because higher bubble proportions would involve a smaller proportion of the paste and weaker resistance against bubble connection [25].

The numerical values of the pore characteristics of the specimens calculated by the Image-Pro Plus 6.0 software in accordance with Figures 2 and 3 are listed in Table 4 . With the increase in w/c ratio, the average pore diameter of the foam concrete increased gradually and the pores became more rounded (Table 4). This finding may be due to the gradual decrease in relative viscosity of cement paste as the w/c ratio increased, thus weakening the bubble-maintaining capacity of the paste. Small bubbles in the paste were easily combined and readily expanded during the stirring process [14]. Meanwhile, the frictional force in the paste reduced, rendering the bubbles increasingly round. Furthermore, the higher dry density of the foam concrete caused decreased the average pore diameter and rendered the pores rounder. A higher paste proportion would generate a smaller bubble proportion, making bubble combination and expansion difficult. 


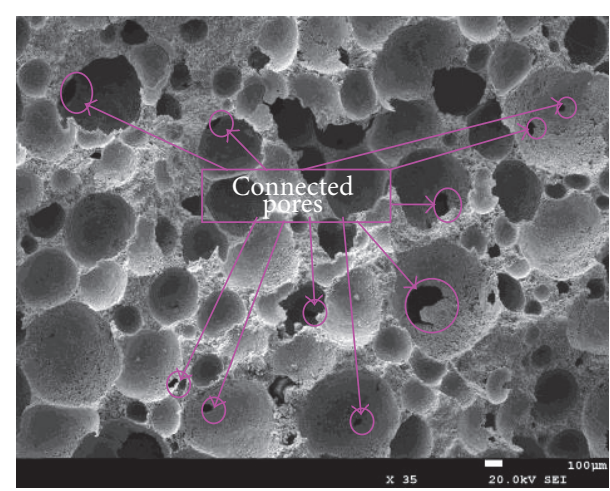

(a) $800-0.40 \times 35$

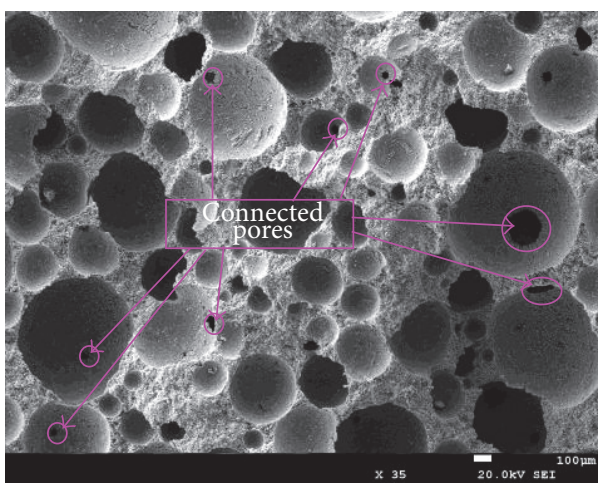

(c) $800-0.50 \times 35$

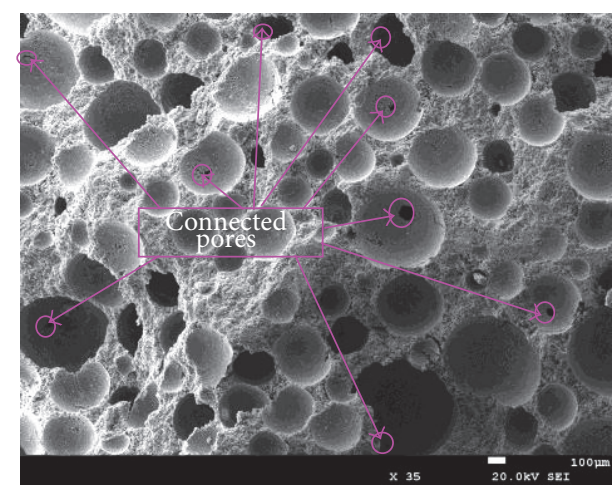

(b) $800-0.45 \times 35$

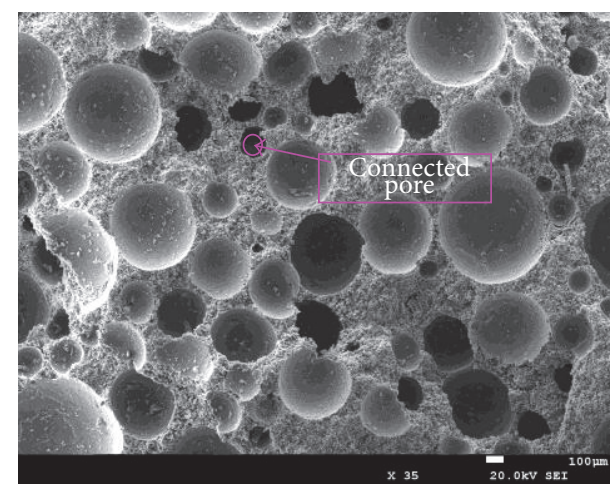

(d) $800-0.55 \times 35$

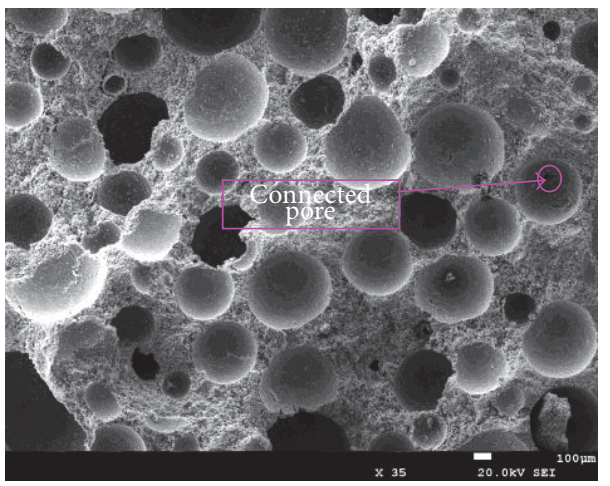

(e) $800-0.60 \times 35$

FIGURE 3: SEM images of the $800 \mathrm{~kg} / \mathrm{m}^{3}$ foam concrete of different w/c ratios.

The effect of $\mathrm{w} / \mathrm{c}$ ratio on the pore diameter distribution of the $500 \mathrm{~kg} / \mathrm{m}^{3}$ foam concrete is shown in Figure 4(a). Small pores $(<100 \mu \mathrm{m})$ in the $500-0.40,500-0.45,500-0.50,500$ 0.55 , and 500-0.60 samples accounted for $23.97 \%, 21.82 \%$, $20.51 \%, 16.0 \%$, and $11.91 \%$, respectively, of the volume. By contrast, the large pores ( $>400 \mu \mathrm{m})$ occupied $10.74 \%, 10.00 \%$, $7.69 \%, 12.0 \%$, and $15.48 \%$, respectively. The pore proportions $(100 \sim 400 \mu \mathrm{m})$, which determined the foam concrete strengths, were $65.29 \%, 68.18 \%, 71.79 \%, 72.00 \%$, and $72.62 \%$, respectively. Results showed that most of the pore diameters in the foam concrete samples ranged between 0 and $400 \mu \mathrm{m}$. With the increase in $\mathrm{w} / \mathrm{c}$ ratio, the proportion of small pores $(<100 \mu \mathrm{m})$ lowered. Meanwhile, the proportion of the pores determining foam concrete strength (100-400 $\mu \mathrm{m})$ changed slightly, whereas the proportion of the large pores $(>400 \mu \mathrm{m})$ was extremely small.

The effect of $\mathrm{w} / \mathrm{c}$ ratio on the pore diameter distribution of $800 \mathrm{~kg} / \mathrm{m}^{3}$ foam concrete is shown in Figure 4(b). Small pores $(<100 \mu \mathrm{m})$ in the $800-0.40,800-0.45,800-0.50,800$ 0.55 , and $800-0.60$ samples accounted for $23.81 \%, 19.15 \%$, $17.86 \%, 11.76 \%$, and $8.45 \%$, respectively, of the volume of the concrete. By contrast, the large pores $(>400 \mu \mathrm{m})$ occupied $7.77 \%, 9.64 \%, 3.57 \%, 10.59 \%$, and $14.08 \%$, respectively. The proportions of pores $(100-400 \mu \mathrm{m})$ that determined the foam concrete strength were $68.42 \%, 71.21 \%, 78.57 \%$, $77.65 \%$, and $77.46 \%$. The pore diameter distribution range 


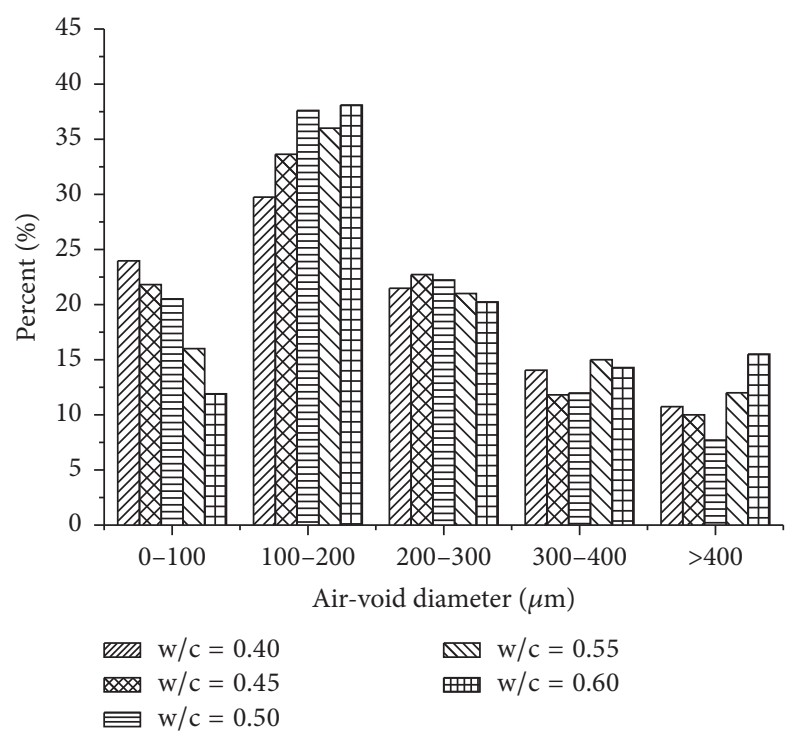

(a) The $500 \mathrm{~kg} / \mathrm{m}^{3}$ foamed concrete

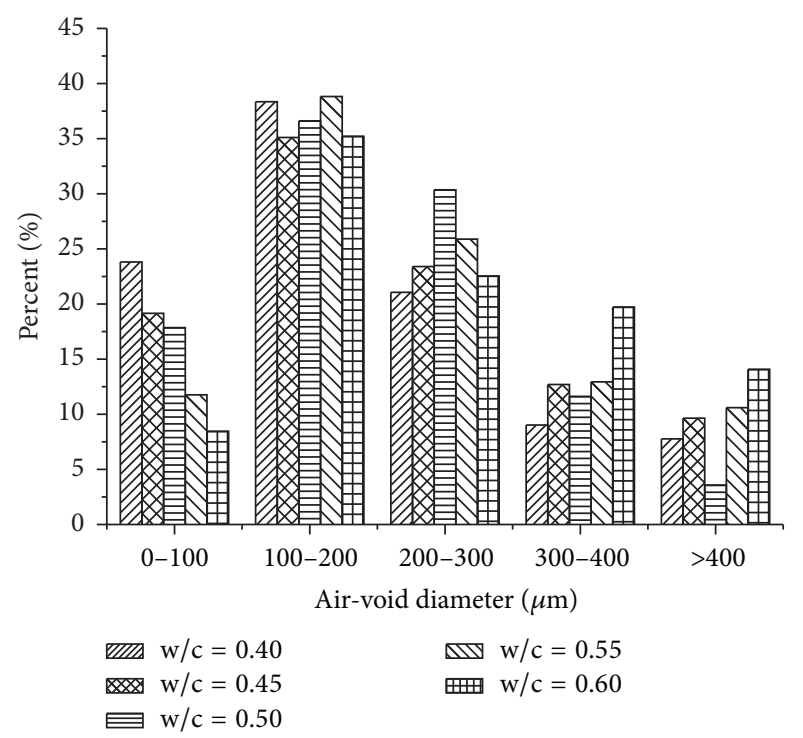

(b) The $800 \mathrm{~kg} / \mathrm{m}^{3}$ foamed concrete

FIGURE 4: Effects of w/c ratio on the pore diameter distribution.

TABLE 4: Characteristics of air pores of the test specimens.

\begin{tabular}{lcc}
\hline Specimens & Mean diameter $(\mu \mathrm{m})$ & Average value of roundness \\
\hline $500-0.40$ & 208.0 & 1.46 \\
$500-0.45$ & 216.3 & 1.41 \\
$500-0.50$ & 217.7 & 1.37 \\
$500-0.55$ & 228.1 & 1.31 \\
$500-0.60$ & 256.1 & 1.30 \\
$800-0.40$ & 192.5 & 1.40 \\
$800-0.45$ & 197.6 & 1.38 \\
$800-0.50$ & 217.0 & 1.36 \\
$800-0.55$ & 226.3 & 1.30 \\
$800-0.60$ & 245.6 & 1.28 \\
\hline
\end{tabular}

in the $800 \mathrm{~kg} / \mathrm{m}^{3}$ foam concrete was narrower than that of the $500 \mathrm{~kg} / \mathrm{m}^{3}$ foam concrete (Figure 4). Moreover, lower proportions of small and large pores were observed. These findings reveal the attributes not beneficial to the strength of the $800 \mathrm{~kg} / \mathrm{m}^{3}$ foam concrete compared with that of the $500 \mathrm{~kg} / \mathrm{m}^{3}$ foam concrete.

The effect of w/c ratio on the porosity of the $500 \mathrm{~kg} / \mathrm{m}^{3}$ foam concrete is illustrated in Figure 5(a). The open porosity of the 500-0.40, 500-0.45, 500-0.50, 500-0.55, and 500-0.60 samples decreased from $49.35 \%$ to $43.70 \%$ gradually, whereas the closed porosity increased from $28.90 \%$ to $34.36 \%$. This finding can be explained by the following reasons. On one hand, the relative viscosity decreased and more bubbles combined with the increase in $\mathrm{w} / \mathrm{c}$ ratio of the foam concrete, thus reducing the total bubble surface area. The cement paste on the bubble surface increased and the pore wall thickened accordingly, as manifested by the reduced open porosity and increased closed porosity. On the other hand, ion enrichment ensued during cement hydration; the solubilities of the different ingredients and migration speeds of the ions differed from one another significantly. Generally, most of the $\mathrm{Ca}^{2+}$, $\mathrm{SO}_{4}{ }^{2-}$, and $\mathrm{Al}^{3+}$ entered the solution and deposited around the bubbles. The higher $\mathrm{w} / \mathrm{c}$ ratio provided conditions for the migration of $\mathrm{Ca}^{2+}, \mathrm{SO}_{4}{ }^{2-}$, and $\mathrm{Al}^{3+}$ [26]. Consequently, calcium hydroxide and ettringite were enriched on the bubble surfaces and formed pore shells. The thickness of pore shells was positively correlated with w/c ratio [27]; hence, the open porosity reduced significantly, whereas the closed porosity increased substantially.

The effect of w/c ratio on the porosity of the $800 \mathrm{~kg} / \mathrm{m}^{3}$ foam concrete is shown in Figure 5(b). The open porosity of the 800-0.40,800-0.45,800-0.50,800-0.55, and 8000.60 samples decreased from $40.15 \%$ to $39.70 \%$ gradually, whereas the closed porosity increased from $22.92 \%$ to $24.08 \%$. However, the variation was not as distinct as that of the $500 \mathrm{~kg} / \mathrm{m}^{3}$ foam concrete. This result is related to the thicker pore walls and fewer open pores in the $800 \mathrm{~kg} / \mathrm{m}^{3}$ foam concrete than in the $500 \mathrm{~kg} / \mathrm{m}^{3}$ sample. Therefore, pore walls may have thickened with the increase in w/c ratio. With the increase in the $w / c$ ratio, then free water evaporated and the amount of capillaries increased [28], which resulted in more capillaries in the $800 \mathrm{~kg} / \mathrm{m}^{3}$ foam concrete than in the $500 \mathrm{~kg} / \mathrm{m}^{3}$ sample, gradually decreasing the open porosity and incrementally augmenting the closed porosity.

3.3. Effect of Pore Structure on the Mechanical Properties of Foam Concrete. The fitting relationships between the measured 28-day strength and dry density of foam concrete are shown in Figure 6. The power exponential relationships between 28 -day strength and dry density varied with $\mathrm{w} / \mathrm{c}$ ratio $(0.4,0.45,0.5,0.55$, and 0.6$)$.

The effect of w/c ratio on the strength of foam concrete is shown in Figure 7 . With the increase in w/c ratio, the 


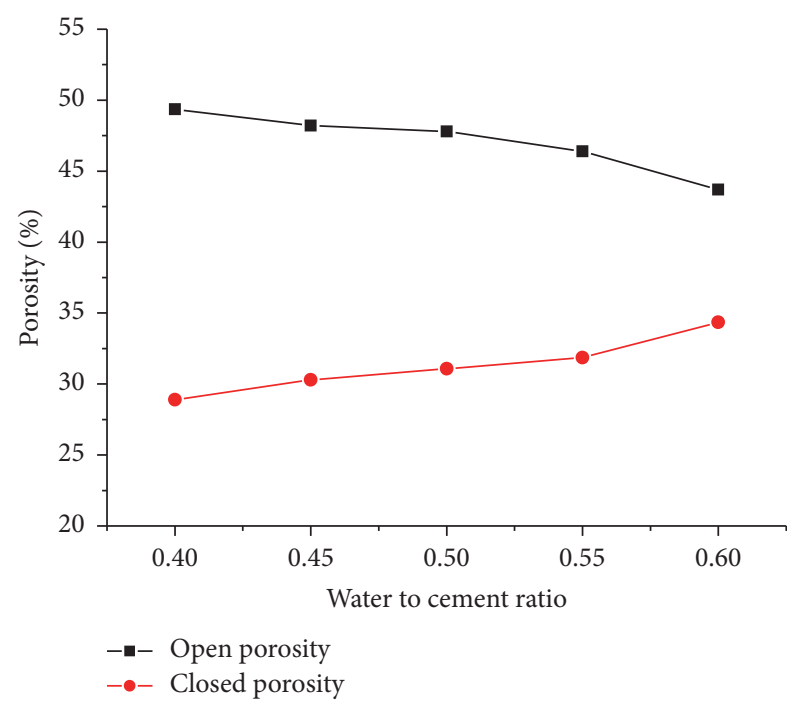

(a) The $500 \mathrm{~kg} / \mathrm{m}^{3}$ foam concrete

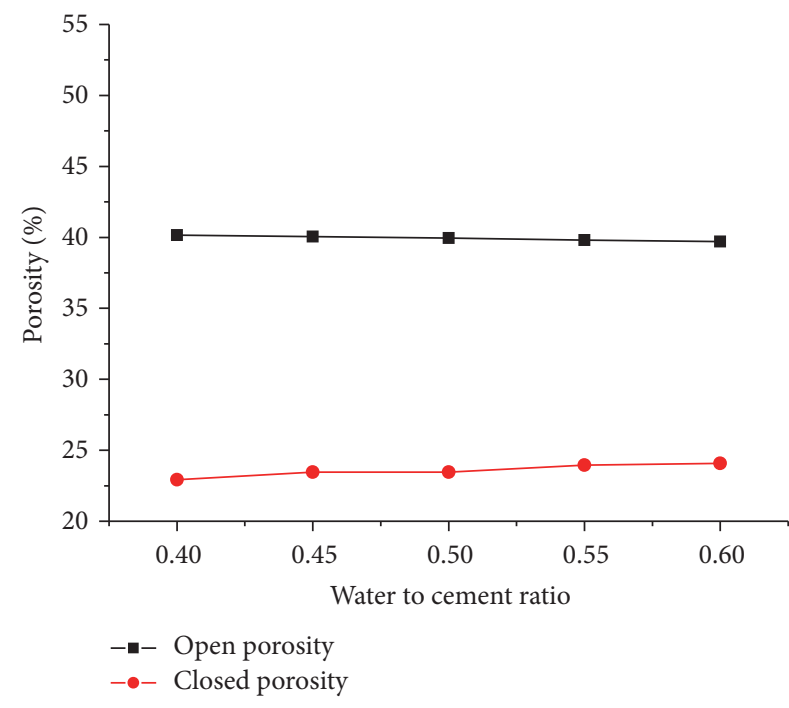

(b) The $800 \mathrm{~kg} / \mathrm{m}^{3}$ foam concrete

FIGURE 5: Effect of the w/c ratio on the porosity of the foam concrete.

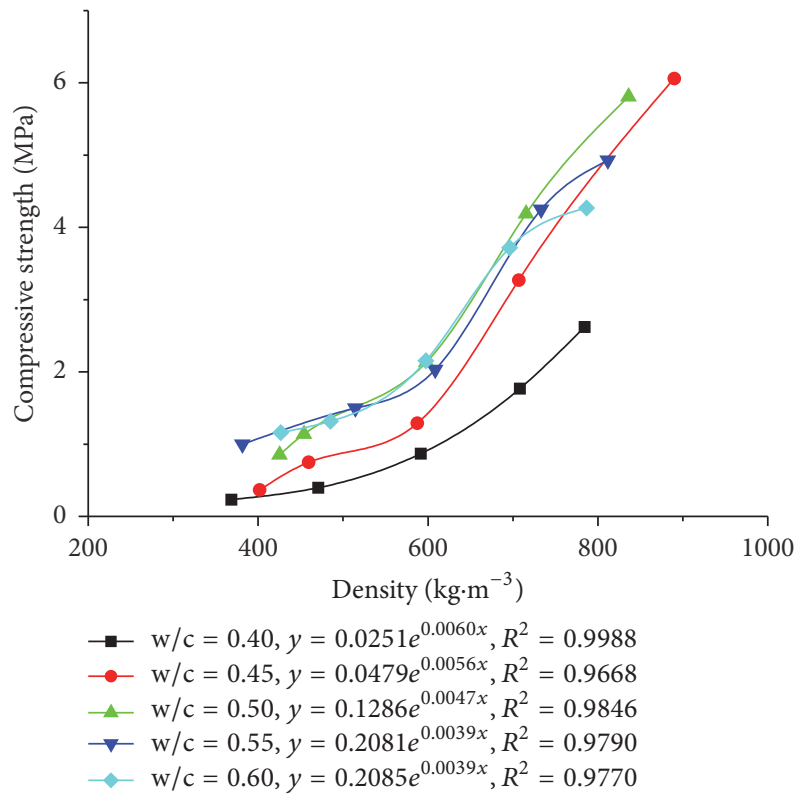

FIGURE 6: The fitting relationships between the strength and dry density of foam concrete.

compressive strength of foam concrete increased first and then decreased. This result was achieved because, on one hand, when the $\mathrm{w} / \mathrm{c}$ ratio was smaller than the optimal ratio, a smaller w/c ratio generated higher proportions of small thin-walled, connected, and irregular pores. The strength of the foam concrete declined upon the stress concentration derived from external forces. On the other hand, the w/c ratio that exceeded the optimal level resulted in a weaker bubblemaintaining capability of the paste. Moreover, the bubbles in the paste easily combined during stirring and resulted in reduced pores, increased pore diameter, and uneven pore distribution. This occurrence would cause stress concentration, and redundant free water would form capillary channels after the hydration reaction of cementing materials or evaporation, negating the compactness of the pore walls and consequently reducing the strength of the foam concrete.

Lower foam concrete dry density generated higher optimal w/c ratio (Figure 7). This finding may be explained by the notion that the lower foam concrete dry density was accompanied by a larger pore distribution range and higher proportions of small and large pores. Small and large pores can introduce defects, causing stress concentration. The defects introduced by small pores, such as connected pores and irregular pores, achieve more serious stress concentrations. Increasing w/c ratios can reduce the proportion of small pores effectively, thus enabling the reduction of stress concentration caused by open, connected, and irregular pores. The optimal w/c ratios of the prepared $400,500,600$, 700 , and $800 \mathrm{~kg} / \mathrm{m}^{3}$ were $0.62,0.59,0.57,0.55$, and 0.53 . The slump values of cement pastes were 215, 208, 204, 200, and $198 \mathrm{~mm}$, respectively. We noted a linear relationship between dry density and the optimal $\mathrm{w} / \mathrm{c}$ ratio expressed as $y=$ $-0.0002 x+0.69$, where $R^{2}=0.991$.

\section{Conclusions}

(1) Given the same density of foam concrete, a higher $\mathrm{w} / \mathrm{c}$ ratio would result in a lower relative viscosity and a weaker bubble-maintaining capacity in cement paste. Moreover, bubbles more easily combine into larger ones. The proportion of small pores reduces, the average pore diameter increases, and the pores become increasingly round.

(2) Given the same foam concrete w/c ratio, lower dry density would widen the pore diameter distribution range and increase the proportions of small and large pores. 


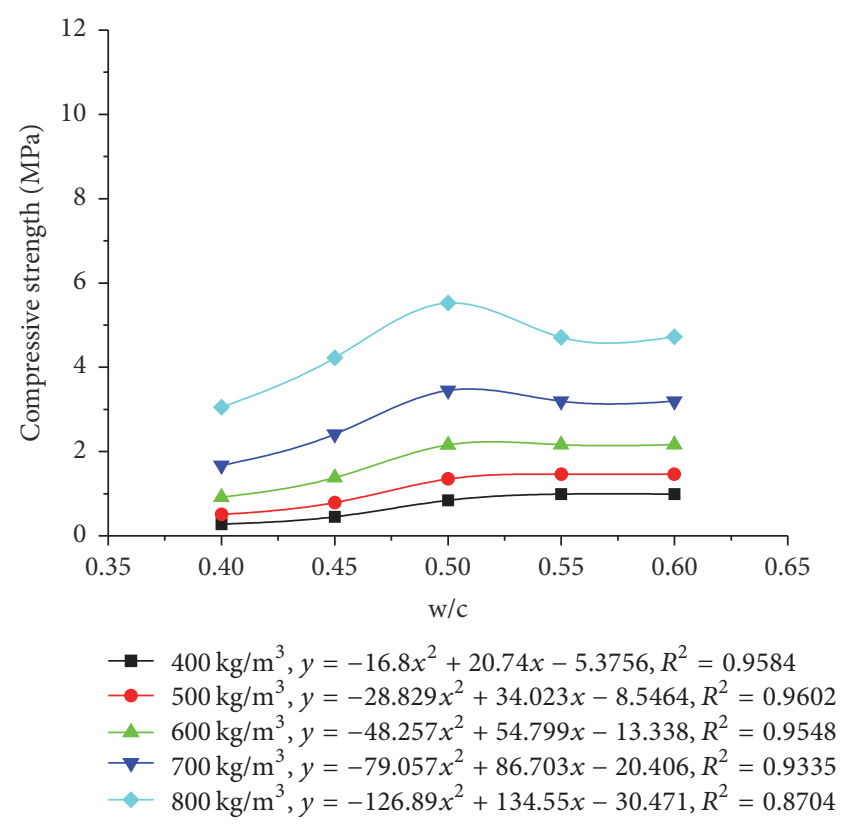

FiguRE 7: Effect of w/c ratio on the strength of foam concrete.

(3) Water-cement ratio influences the size, shape, distribution, and connectivity of pores in foam concrete. The power exponential relationship between 28-day strength and dry density of the foam concrete varies with different $\mathrm{w} / \mathrm{c}$ ratios.

(4) A linear relationship exists between dry density and optimal w/c ratio expressed as $y=-0.0002 x+0.69$, where $R^{2}=0.991$. The optimal $\mathrm{w} / \mathrm{c}$ ratios of the prepared $400,500,600,700$, and $800 \mathrm{~kg} / \mathrm{m}^{3}$ were 0.62 , $0.59,0.57,0.55$, and 0.53 , respectively.

\section{Competing Interests}

The authors declare that there is no conflict of interests regarding the publication of this paper.

\section{Acknowledgments}

The authors would like to acknowledge the support from the National Natural Science Foundation of China (no. 51372199).

\section{References}

[1] Y. H. Mugahed Amran, N. Farzadnia, and A. A. Abang Ali, "Properties and applications of foamed concrete; a review," Construction \& Building Materials, vol. 101, pp. 990-1005, 2015.

[2] P. Chindaprasirt and U. Rattanasak, "Shrinkage behavior of structural foam lightweight concrete containing glycol compounds and fly ash," Materials and Design, vol. 32, no. 2, pp. 723-727, 2011.

[3] X. Chen, Y. Yan, Y. Liu, and Z. Hu, "Utilization of circulating fluidized bed fly ash for the preparation of foam concrete," Construction \& Building Materials, vol. 54, pp. 137-146, 2014.
[4] K. Jitchaiyaphum, T. Sinsiri, and P. Chindaprasirt, "Cellular lightweight concrete containing pozzolan materials," Procedia Engineering, vol. 14, no. 11, pp. 1157-1164, 2011.

[5] J.-Y. Wang, M.-H. Zhang, W. Li, K.-S. Chia, and R. J. Y. Liew, "Stability of cenospheres in lightweight cement composites in terms of alkali-silica reaction," Cement \& Concrete Research, vol. 42, no. 5, pp. 721-727, 2012.

[6] C. Hu, H. Li, Z. Liu, and Q. Wang, "Research on properties of foamed concrete reinforced with small sized glazed hollow beads," Advances in Materials Science and Engineering, vol. 2016, Article ID 5820870, 8 pages, 2016.

[7] A. A. Sayadi, J. V. Tapia, T. R. Neitzert, and G. C. Clifton, "Effects of expanded polystyrene (EPS) particles on fire resistance, thermal conductivity and compressive strength of foamed concrete," Construction and Building Materials, vol. 112, pp. 716724, 2016.

[8] M. Y. J. Liu, U. J. Alengaram, M. Z. Jumaat, and K. H. Mo, "Evaluation of thermal conductivity, mechanical and transport properties of lightweight aggregate foamed geopolymer concrete," Energy \& Buildings, vol. 72, pp. 238-245, 2014.

[9] U. Johnson Alengaram, B. A. Al Muhit, M. Z. bin Jumaat, and M. L. Y. Jing, "A comparison of the thermal conductivity of oil palm shell foamed concrete with conventional materials," Materials of Design, vol. 51, pp. 522-529, 2013.

[10] Z. Zhang, J. L. Provis, A. Reid, and H. Wang, "Mechanical, thermal insulation, thermal resistance and acoustic absorption properties of geopolymer foam concrete," Cement \& Concrete Composites, vol. 62, pp. 97-105, 2015.

[11] S. Wei, C. Yiqiang, Z. Yunsheng, and M. R. Jones, "Characterization and simulation of microstructure and thermal properties of foamed concrete," Construction \& Building Materials, vol. 47, no. 10, pp. 1278-1291, 2013.

[12] G.-C. Sang, Y.-Y. Zhu, G. Yang, and H.-B. Zhuang, "Influence of water-cement ratio on property of light weight cement based foam material," Journal of Materials Science and Engineering, vol. 33, no. 3, pp. 339-342, 2015.

[13] J. Jiang, Z. Lu, Y. Niu, J. Li, and Y. Zhang, "Study on the preparation and properties of high-porosity foamed concretes based on ordinary Portland cement," Materials \& Design, vol. 92, pp. 949-959, 2016.

[14] G. Sang, Y. Zhu, G. Yang, and H. Zhang, "Preparation and characterization of high porosity cement-based foam material," Construction \& Building Materials, vol. 91, pp. 133-137, 2015.

[15] T.-H. Wee, S. B. Daneti, and T. Tamilselvan, "Effect of w/c ratio on air-void system of foamed concrete and their influence on mechanical properties," Magazine of Concrete Research, vol. 63, no. 8, pp. 583-595, 2011.

[16] C. Krämer, M. Schauerte, T. L. Kowald, and R. H. F. Trettin, "Three-phase-foams for foam concrete application," Materials Characterization, vol. 102, pp. 173-179, 2015.

[17] C. Krämer, T. L. Kowald, and R. H. F. Trettin, "Pozzolanic hardened three-phase-foams," Cement \& Concrete Composites, vol. 62, pp. 44-51, 2015.

[18] M. T. Ley, R. Chancey, M. C. G. Juenger, and K. J. Folliard, "The physical and chemical characteristics of the shell of air-entrained bubbles in cement paste," Cement \& Concrete Research, vol. 39, no. 5, pp. 417-425, 2009.

[19] A. A. Hilal, N. H. Thom, and A. R. Dawson, "On entrained pore size distribution of foamed concrete," Construction \& Building Materials, vol. 75, pp. 227-233, 2015. 
[20] A. A. Hilal, N. H. Thom, and A. R. Dawson, "On void structure and strength of foamed concrete made without/with additives," Construction \& Building Materials, vol. 85, pp. 157-164, 2015.

[21] K. Yang and K. Lee, "Tests on alkali-activated slag foamed concrete with various water-binder ratios and substitution levels of fly ash," Journal of Building Construction \& Planning Research, vol. 1, no. 1, pp. 8-14, 2013.

[22] S. Wei, Z. Yunsheng, and M. R. Jones, "Using the ultrasonic wave transmission method to study the setting behavior of foamed concrete," Construction \& Building Materials, vol. 51, no. 51, pp. 62-74, 2014.

[23] A. K. H. Kwan, W. W. S. Fung, and H. H. C. Wong, "Water film thickness, flowability and rheology of cement-sand mortar," Advances in Cement Research, vol. 22, no. 1, pp. 3-14, 2010.

[24] Z. Qian, L. Li, Z. Gao, and F. Hu, "Research on the effect of different superplasticizers on the properties of foam concrete," Coal Ash, no. 6, pp. 44-46, 2014.

[25] M. Zhu, F.-G. Wang, X.-L. Zhang, and F.-Z. Wang, "Research on the relationship between pore structure and thermal conductivity of foamed doncrete," Journal of Wuhan University of Technology, vol. 35, no. 3, pp. 20-25, 2013.

[26] L. Wang, Y. Chen, and G. Du, "Influence mechanism of microstructure of foam concrete on macroscopic properties," China Powder Science and Technology, vol. 21, no. 5, pp. 63-68, 2015.

[27] Y. Xie, D. J. Corr, F. Jin, H. Zhou, and S. P. Shah, "Experimental study of the interfacial transition zone (ITZ) of model rockfilled concrete (RFC)," Cement \& Concrete Composites, vol. 55, pp. 223-231, 2015.

[28] X. Li, M. Liu, B. Ma, S. Jian, L. Su, and Z. Zhao, "Influence of pore structure on foam concrete and controlling method," Materials Review, vol. 26, no. 4, pp. 141-144, 2012. 

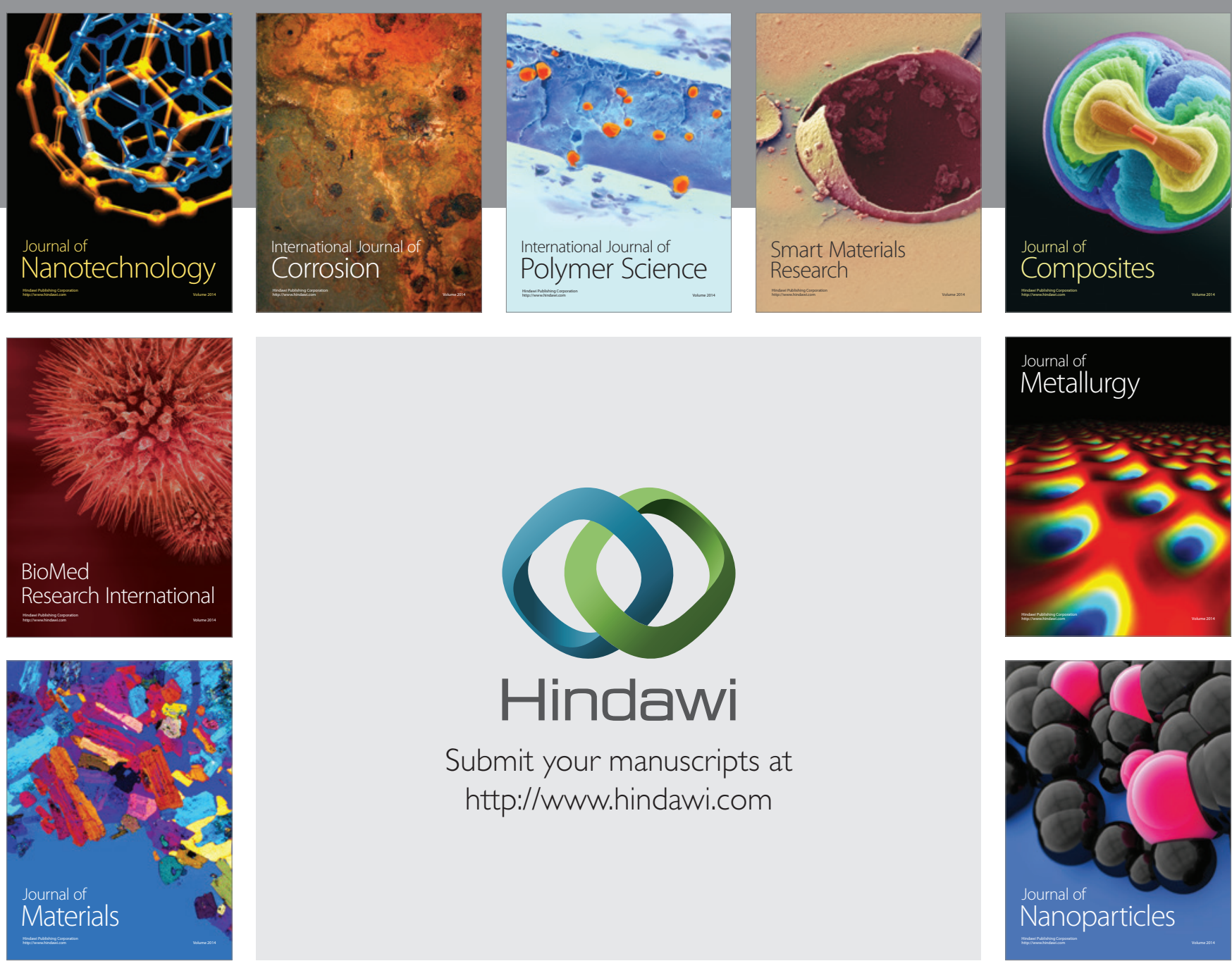

\section{Hindawi}

Submit your manuscripts at

http://www.hindawi.com

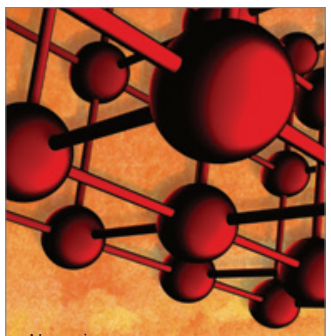

Materials Science and Engineering
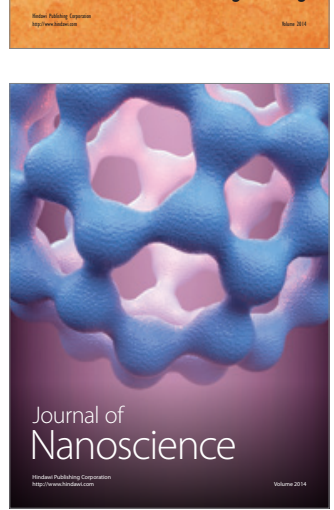
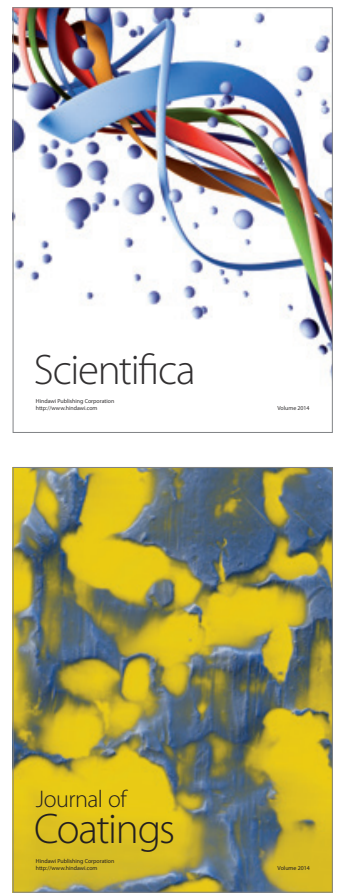
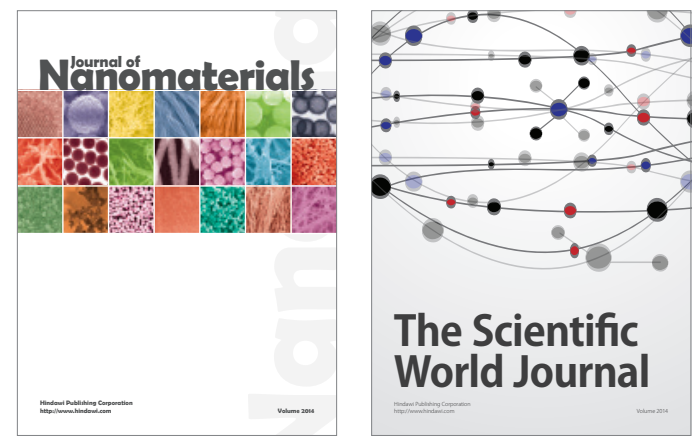

The Scientific World Journal
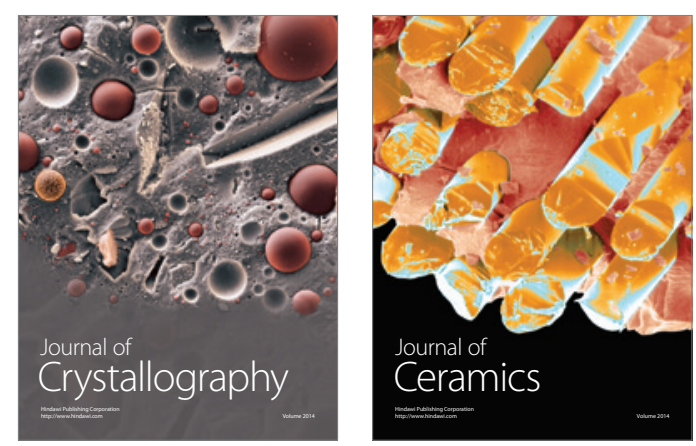
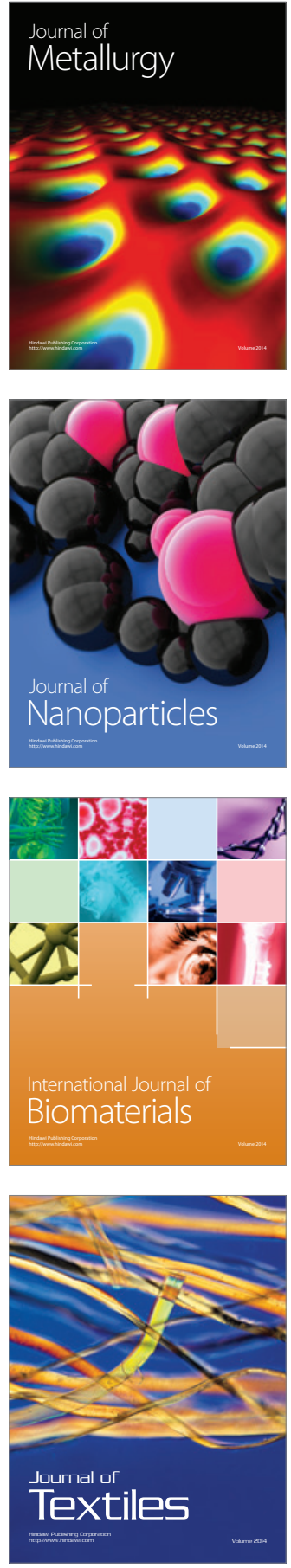